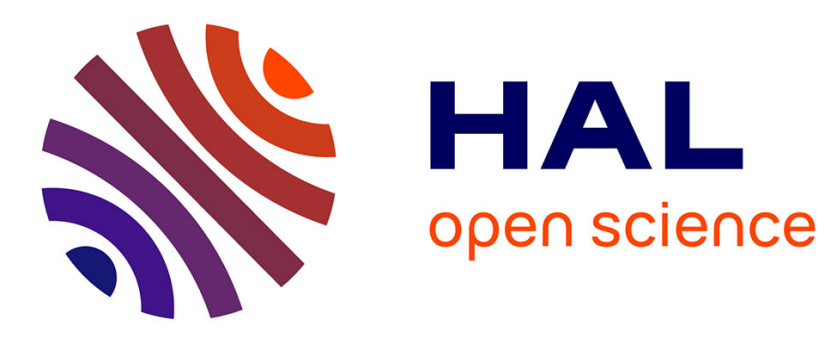

\title{
Empowering biodiversity knowledge
}

Vincent Devictor, Yves Meinard

\section{To cite this version:}

Vincent Devictor, Yves Meinard. Empowering biodiversity knowledge. Conservation Biology, 2020, 34 (2), pp.527-529. 10.1111/cobi.13367 . hal-03086845

\section{HAL Id: hal-03086845 https://hal.science/hal-03086845}

Submitted on 28 Dec 2020

HAL is a multi-disciplinary open access archive for the deposit and dissemination of scientific research documents, whether they are published or not. The documents may come from teaching and research institutions in France or abroad, or from public or private research centers.
L'archive ouverte pluridisciplinaire HAL, est destinée au dépôt et à la diffusion de documents scientifiques de niveau recherche, publiés ou non, émanant des établissements d'enseignement et de recherche français ou étrangers, des laboratoires publics ou privés. 


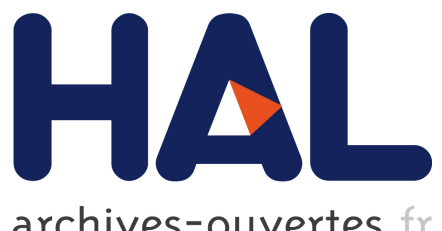

archives-ouvertes

\section{Empowering biodiversity knowledge}

Vincent Devictor, Yves Meinard

\section{To cite this version:}

Vincent Devictor, Yves Meinard. Empowering biodiversity knowledge. Conservation Biology, Wiley, 2020, 34 (2), pp.527-529. 10.1111/cobi.13367 . hal-03086845

\section{HAL Id: hal-03086845 \\ https://hal.archives-ouvertes.fr/hal-03086845}

Submitted on 28 Dec 2020

HAL is a multi-disciplinary open access archive for the deposit and dissemination of scientific research documents, whether they are published or not. The documents may come from teaching and research institutions in France or abroad, or from public or private research centers.
L'archive ouverte pluridisciplinaire HAL, est destinée au dépôt et à la diffusion de documents scientifiques de niveau recherche, publiés ou non, émanant des établissements d'enseignement et de recherche français ou étrangers, des laboratoires publics ou privés. 


\title{
Empowering biodiversity knowledge
}

\author{
Vincent Devictor ${ }^{1}$ and Yves Meinard (1D ${ }^{2}$ \\ ${ }^{1}$ SEM, Université de Montpellier, CNRS, IRD, EPHE, Montpellier, France \\ ${ }^{2}$ LAMSADE, CNRS, [UMR 7243], Université Paris-Dauphine, PSL Research University, 75016, Paris, France, email \\ yves.meinard@lamsade.dauphine.fr
}

\section{Introduction}

Conservation sciences are inundated by academic warnings to humanity and calls for better environmental governance, presupposing that biodiversity science provides a descriptive picture on the basis of which decision makers can make cogent policy choices. We challenge this view and argue that discourses on biodiversity have become a rhetorical veneer hiding academic strategies to optimize funding and an opiate sustaining the comfortable belief that biodiversity knowledge unquestionably contributes to the mitigation of biodiversity loss. The hard truth is that the space separating scientists from policy makers is not a no-man's-land through which scientists can throw their recommendations to decision makers on the other side. This space is saturated by processes that distort, construct, and erase information, and are currently more efficient in consolidating the illusion that a global governance is being constructed, than in stanching the crisis. Rather than turning a blind eye to these processes, we need to invent new ways to empower biodiversity knowledge.

\section{Ubiquity of Politics in Biodiversity Science}

Biodiversity science has always been intermingled with political agendas. The emergence of concern for biodiversity coincides with the abandonment of teleological reference states to explain ecosystem dynamics. Population dynamics and individual species selection and adaptation replaced higher systemic levels as focal units, compromising the hope that the course of nature could be predicted and managed. The Odumian vision, according to which ecological succession is an orderly and predictable process, was replaced by neo-Gleasonian nonequilibrium theories (Pickett \& White 1985). This development shifted the focus of conservation toward individual species, their habitats, threats, and conservation status (Forsyth 2003).

In this context, articulating conservation issues in terms of data, in the wake of Wilson's original estimates of species richness, was presented as a means to "translate good science... into good politics" (Kelmelis \& Snow 1991). The emergence of the term biodiversity was part of a "political mission" to draw the U.S. Congress's attention on the "species extinction crisis" (Takacs 1996). This advocacy rapidly gained scientific credence (Soulé \& Wicox 1980), and calls for integrating political constraints on biodiversity quantification soon followed (Walker 1992). The development of a "functional approach" that admits "global biodiversity concerns will ultimately reduce to a cost-benefit analysis" was endorsed by scientists and practitioners. Biodiversity was interpreted as a reservoir of functional attributes, liable to fulfil political and social needs. The difficult challenge to entrench the political acceptability of the moral basis of conservation (Soulé 1985) was bypassed by reconfiguring environmental issues in instrumental terms (Bonneuil 2015). By considering biodiversity and ecosystem services as 2 faces of the same coin, succeeding initiatives (e.g., Potsdam Initiative, Millenium Ecosystem Assessment) embarked on a political crusade to reduce the value of biodiversity to its contribution to an abstract and vague human well-being.

The emergence of global data on and maps of biodiversity is itself politically oriented (Devictor \& Bensaude-Vincent 2016). Their seeming neutrality feeds a political fantasy of global environmental governance (Turnhout et al. 2016), and global information platforms on biodiversity, presented as means to facilitate

Both the authors contributed equally to this work.

Article impact statement: Biodiversity knowledge, which is increasingly reduced to rbetoric biding academic strategies and an anxiolytic, needs to be re-empowered.

Paper submitted February 27, 2019; revised manuscript accepted June 7, 2019. 
biotechnological innovation (OCDE 1999), rest on a politically loaded vision of society and the role of science (Biermann et al. 2015).

\section{Vacuous Rhetoric of an Allegedly Policy-Relevant Biodiversity Science}

The importance of politics within biodiversity science reflects an academic legitimization rhetoric. Early in the history of biodiversity science, some ecologists stumbled on the idea they could sell their research to funding agencies by claiming that ecological knowledge is policy relevant because biodiversity is important for human well-being (Dempsey \& Robertson 2012). This is a gratuitous idea, only vaguely buttressed on a schematic understanding of human well-being and barely integrated in a vision of how this supposedly policy-relevant knowledge could be used by policy makers. The scientific leader of the first forum on biodiversity and ecosystem function accordingly stated that endorsing the relationship between biodiversity and ecosystem services "provides a powerful link between research in basic ecology and the interests of the general public and policy makers" (Mooney 1998).

Such a narrative carelessly touting policy relevance to capture funding also probably plays a role in other scientific fields. The direct benefit of conservation to society is, however, less clear than the industrial and commercial products of physics or chemistry, forcing important distortions of conservation discourses.

This legitimization rhetoric struck a chord with economists because it bolstered their promotion of the concept of ecosystem services (Jepson 2005). A synergy of academic legitimization emerged and unified economists and ecologists around research programs on, for example, the link between biodiversity and ecosystem functioning. A bonanza of funding was secured and resulted in an avalanche of supposedly policy-relevant publications and fed an overstretched narrative of promise and hope for global biodiversity governance. Ecologists left unmoored by the demise of Odumian teleology were thereby provided with an opiate that alleviated their anxiety (an anxiolytic) by entertaining their hope of finding a new balance with nature to replace the lost balance of nature (Simberloff 2014). This anxiolytic conservation science (Garnett \& Lindenmayer 2011), presenting environmental issues as reducible to manageable technical problems, even allowed championing enthusiastic and bombastic development goals for "people and the planet" (Griggs et al. 2015).

The scientists involved in the origin of the term biodiversity did not foresee these developments, but found themselves caught in a series of decentralized, undirected processes that caused biodiversity knowledge to drift in a certain direction, including the construction of databases disconnected from field work and the forging of tighter links between ecology and economic valuation.

Yet far from witnessing the practical success of this biodiversity knowledge, prominent supposedly policyrelevant academic tools, such as valuations of ecosystem services, are rarely used (Laurans et al. 2013) and political initiatives to stop the erosion of biodiversity are either missing or insufficient. Biodiversity knowledge thus increasingly seems merely a powerless discourse proliferating in insolation from environmental policies.

\section{Empowering Biodiversity Knowledge}

We do not claim that biodiversity science is nothing but a vacuous rhetoric or that the biodiversity crisis is fantasy. Empirical evidence shows that many biophysical entities are imperiled by increasing anthropogenic impacts (Godet \& Devictor 2018). These biophysical aspects of the biodiversity crisis are not, however, the subject matter of a non-normative knowledge. Biodiversity, biodiversity crisis, and conservation science have normative aspects: people engaged in conservation are motivated by a moral or ethical call whose contours are a subject of ongoing philosophical debate and reflexive scrutiny by conservationists (Vucetich et al. 2015). The aspect of politically loaded discourses geared to fund raising we criticize is not the normative dimension per se, but rather the selective presentation of evidence and gratuitous promises. Evidence is selected to construct a discourse designed to capture funds for researchers and nongovernmental organizations, rather than to develop interventions to contravene the crisis. And this discourse is structured around grandiloquent but gratuitous promises to stop the erosion of biodiversity, which arguably explains why so many conservation scientist and activists, motivated at root by their moral and ethical impulses, endorse a strategy manifestly geared toward capturing money and personal recognition.

Major contributions by those who anticipated as early as the 1980s that biodiversity science was a vehicle for a political agenda can be used to identify how to get out of this predicament. In the context of neoliberal globalization, struggles for local autonomy and knowledge have relentlessly challenged attempts to impose governance models for biodiversity (Escobar 2008). In a similar vein, anthropological studies show that in what we, Western scientists, disdainfully call "local communities," people can be incredibly discerning and creative in manipulating discourses and institutions that we ingenuously conceive as being devoted to biodiversity conservation (Hanson 2009).

The first lesson we should learn from these approaches has to do with the words we use. Language choices can undercut our mission (Johns \& Dellasala 2017). 
If euphemism and buzzwords are blindly accepted, unsubstantiated assertions about how biodiversity contributes to ecosystem function and human well-being invade our reasoning (Goldstein 2012). Beyond word usage, efforts to reveal the values and goals underlying biodiversity discourses are needed to overcome the debilitating myth of consensus (Peterson et al. 2005).

As a first step toward acknowledging this normative complexity, we could venture interpretations of the political significance of our work by highlighting, for example, the need to couple ecological work on invasive species with socioeconomic reflections on globalization. In the same vein, we could make it a rule to attempt (informal and tentative) multidimensional impact assessments of our work. For example, instead of complacently highlighting conservation implications, we could highlight how many kilometers we traveled to develop our projects and promote them and the contributions of our work to global change.

Such information would usefully raise awareness that our actions are more equivocal than we assume. However, they should not feed the illusion that virtuous individual action is the key to solve global environmental problems. They should be part of a broader attitude through which we step back and critically analyze the settings in which we act and think. We need to take it upon ourselves to manipulate the available discourses and institutions by taking them as they are (that is, as elements of a strong and resistant politically loaded processes), rather than as we want them to be (that is, as faithful and transparent attempts to solve the biodiversity crisis).

\section{Acknowledgments}

We thank 2 anonymous reviewers and B. Callicott for their important suggestions and constructive criticisms.

\section{Literature Cited}

Biermann F, Abbott K, Andresen S, Bäckstrand K, Bernstein S, Betsill MM, Bulkeley H. 2015. Navigating the anthropocene: Improving earth system governance. Science 335:13061307.

Bonneuil C. 2015. Tell me where you come from, I will tell you who you are: A genealogy of biodiversity offsetting mechanisms in historical context. Biological Conservation 192:485-491.
Dempsey J, Robertson MM. 2012. Ecosystem services: Tensions, impurities, and points of engagement within neoliberalism. Progress in Human Geography 36:758-779.

Devictor V, Bensaude-Vincent B. 2016. From ecological records to big data: The invention of global biodiversity. History and Philosophy of the Life Sciences 38:13.

Escobar A. 2008. Territories of difference. Duke University Press Books, Durham, North Carolina.

Forsyth T. 2003. Critical political ecology: the politics of environmental science. Routledge, New York.

Garnett ST, Lindenmayer DB. 2011. Conservation science must engender hope to succeed. Trends in Ecology \& Evolution 26:59-60.

Godet L, Devictor V. 2018. What conservation does. Trends in Ecology \& Evolution 33:720-730.

Goldstein PZ. 2012. Functional ecosystems and biodiversity buzzwords. Conservation Biology 13:247-255.

Griggs D, et al. 2015. Sustainable development goals for people and planet. Nature 495:305-307.

Hanson PH. 2009. Engaging green governmentality through ritual. Études Océan Indien 42-43:85-113.

Jepson P. 2005. Governance and accountability of environmental NGOs. Environmental Science \& Policy 8:515-524.

Johns D, Dellasala DA. 2017. Caring, killing, euphemism and George Orwell: how language choice undercuts our mission. Biological Conservation 211:174-176.

Kelmelis JA, Snow M, editors. 1991. Proceedings of the U.S. Geological Survey Global change research forum. Circular 1086. U.S. Geological Survey, Denver.

Laurans Y, Rankovic A, Billé R, Pirard R, Mermet L. 2013. Use of ecosystem services valuation for decision-making: Questioning a literature blindspot. Journal of Environmental Management 119:208-219.

Mooney HA. 1998. The globalization of ecological thought (excellence in ecology). International Ecology Institute, Oldendorf.

OCDE (Organisation for Economic Co-operation and Development). 1999. Final report of the OECD megascience forum. OCDE, Paris.

Peterson MN, et al. 2005. Conservation and the myth of consensus. Conservation Biology 19:762-767.

Pickett STA, White PS, editors. 1985. The ecology of natural disturbance and patch dynamics. Academic Press, New York.

Simberloff D. 2014. The "balance of nature"--evolution of a panchreston. PLOS Biology 12 (e1001963) http://doi.org/10. 1371/journal.pbio.1001963.

Soulé ME. 1985. What is conservation biology? BioScience 35:727-734.

Soulé ME, Wilcox BA. 1980. Conservation biology: an evolutionaryecological perspective. Sinauer Associates, Sunderland, Massachusetts.

Takacs D. 1996. The idea of biodiversity: philosophies of paradise. Johns Hopkins University Press, Baltimore, Maryland.

Turnhout E, Dewulf A, Hulme M. 2016. What does policy-relevant global environmental knowledge do? The cases of climate and biodiversity. Current Opinion in Environmental Sustainability 18:65-72.

Vucetich JA, Bruskotter JT, Nelson MP. 2015. Evaluating whether nature's intrinsic value is an axiom of or anathema to conservation. Conservation Biology 29:1-12.

Walker BH. 1992. Biodiversity and ecological redundancy. Conservation Biology 6:18-23. 